\title{
Factors Influencing Customers to Use Digital Banking Application in Yogyakarta, Indonesia
}

\author{
Muhammad MUFARIH ${ }^{1}$, Riyanto JAYADI ${ }^{2}$, Yovin SUGANDI ${ }^{3}$
}

Received: July 15, 2020 Revised: September 06, 2020 Accepted: September 10, 2020

\begin{abstract}
The development of information technology and the demands of society on an application in an operating system, as well as increasing the specifications and sophistication of smartphones, require banks to make changes to their mobile banking applications. The transformation of the mobile banking application into a digital banking application conducted by banks has made users re-evaluate based on their preferences. This study presents the behavior of users of digital banking applications in Yogyakarta, Indonesia. The hypothesis model is based on Technology Acceptance Model (TAM) with additional factors of the social image, perceived risk and perceived trust adopted from MuñozLeiva et al. (2017). The methodology in this study includes data collection through questionnaires distributed online and data analysis using the Structural Equation Model. The results of this study illustrate that the perceived trust and perceived risk have a more dominant part in influencing user attitude and user intention to use digital banking. Meanwhile, social image, perceived ease-of-use and perceived usefulness are not significant in influencing user attitude and user intention to use digital banking. The implication of this research helps to determine the right communication and strategy so that more users with more benefits can utilize this digital banking application.
\end{abstract}

Keywords: Mobile Banking, User Behavior, Social Image, Perceived Trust, Perceived Risk, Attitude

JEL Classification Code: G21, G41, O33

\section{Introduction}

Although mobile banking is not a new technology, for banking customers in general, this technology helps them to carry out daily banking activities. Digital banking is an

${ }^{1}$ First Author. Information Systems Management Department, BINUS Graduate Program - Master of Information Systems Management, Bina Nusantara University, Jakarta, Indonesia.

Email: muhammad.mufarih@binus.ac.id.

${ }^{2}$ Corresponding Author. Information Systems Management Department, BINUS Graduate Program - Master of Information Systems Management, Bina Nusantara University, Jakarta, Indonesia [Postal Address: Jl. K. H. Syahdan No. 9, Kemanggisan, Palmerah, Jakarta, 11480, Indonesia]

Email: riyanto.jayadi@binus.edu.

IInformation Systems Management Department, BINUS Graduate

Program - Master of Information Systems Management, Bina

Nusantara University, Jakarta, Indonesia.

Email: yovin.sugandi@binus.ac.id

(c) Copyright: The Author(s)

This is an Open Access article distributed under the terms of the Creative Commons Attribution Non-Commercial License (https://creativecommons.org/licenses/by-nc/4.0/) which permits unrestricted non-commercial use, distribution, and reproduction in any medium, provided the original work is properly cited. e-commerce application that is delivered by a financial institution or bank that allows its users to conduct financial transactions remotely by adopting a mobile device (Baabdullah et al., 2019). Digital banking is an excellent example of a cellular technology breakthrough in the banking sector, which allows customers to independently carry out financial transactions, such as balance information, fund transfers, bill payments, and other transaction, through mobile devices, smartphones or other devices at a time and place customer-selected (Alalwan et al., 2017).

The use of digital banking cannot be separated from the penetration of mobile devices that are very massive in Indonesia. The total population of Indonesian in January 2019 is known to be 268.2 million. However, there are 355.5 million users, making the percentage of mobile users $133 \%$, greater than the original number of Indonesians.

Nowadays, technology has changed the way consumers want to interact. Apart from factors such as speed, comfort, consistency, and friendliness, the human touch is also one of the main factors that support the user experience. Creating real relationships by making technology feel more human can create a better customer experience and is very important for the development of this industry. For banks, user experience 
is significant; based on the Pricewaterhouse Coopers survey, $94 \%$ of respondents agree that customer experience is part of developing business strategies, $40 \%$ of respondents associate with company strategy, $22 \%$ of respondents consider it as consumer strategy, $18 \%$ of respondents see it as a digital strategy, and $8 \%$ of respondents consider it as product strategies (PricewaterhouseCoopers, 2018).

Based on consideration of customer needs and fraud risk in cyberspace transactions, the actual digital banking application could become the main channel for banking in Indonesia. This strategy was reinforced by the rapid acceleration of customer growth from 2013 to the last few years. However, for some conventional customers there is still reluctance or concern to use a digital banking application, in addition to lack of experience and security, and also because one of the prominent characteristics of using digital banking in Indonesia is that connectivity depends on the banking application used and network availability from existing cellular operators (Pousttchi \& Schurig, 2004). The banking sector, like other sectors, makes the Internet and mobile applications as one of the most effective channels in offering banking products. Therefore, there is an increase in banking competition to balance increasing customer demand (Shaikh \& Karjaluoto, 2014).

Banks are required to provide the best service following customer expectations, so that some banks make changes/ transformations on a large scale, including digital transformation. Digital banking, which was initially an application with standard transaction features, has been changed into an application with a variety of functions, ranging from opening savings and investment accounts, withdrawal without cards, real-time gross settlement, redeem points, shopping, and several other types of transactions.

Noting the background above, when there is a change in technology, in this case, the application changes, there will always appear two statements, namely, whether the application is better or worse or whether it is more desirable or not desirable. In order to convey this interest, the Acceptance Model theory developed by Davis (1989) states that the usage of an application system is motivated by behavioral purpose, where the value is affected by the interpretation of the consumer (beliefs) in the form of perceived usefulness of the order and perceived ease of use. An application that is easy to use will attract customers; also, there is a significant positive relationship between expectations and ease of use so that in the end the customer's perception of the usefulness of the application will be directly influenced by its userfriendly application (Voon et al., 2015). The most substantial influence on behavioral intention is perceived conformity.

On the other hand, other variables have a significant impact on behavioral intentions, namely, reputation, performance expectations, effort expectations, and social influence (Rilling \& Debbie Harrison, 2015). Several other studies focus on the factors that influence the acceptance of mobile applications from a holistic approach that integrates several principles related to theories of trust, risk, and social image (Liebana-Cabanillas et al., 2017) or social influences or subjective norms.

Technology acceptance is also influenced by one's positive and negative attitudes (Parasuraman, 2000). The concept of consumer attitudes towards the use of technology-based products and services can be explained in the technologyreadiness variable. Someone with a high positive attitude in responding to the existence of technology tends to easily use technology, conversely if a someone has an adverse reaction, it will constitute an entry barrier to information.

Several previous studies has been conducted in this area. Le et al., 2020 conducted a study on the behavior of customers of banks in Vietnam who have not used mobile banking and those who have used it. The focus of this research was to identify factors that influence customer decisions in using mobile banking. The results of this study indicate that the social influence factor has more impact on customer decisions. Other factors, such as the influence of perceived ease-of-use and perceived trust, are not dominant compared to social influence (Le et al., 2020). Nguyen (2020) studied the factors affecting the intention to use digital banking in Vietnam using structural equation modeling. The author found that perceived usefulness has a positive effect on attitude and intention to use the service in Vietnam. In comparison, perceived risk has a negative impact on attitude towards the service. In terms of the studies on Indonesian banking, customer trust toward Islamic banking in Indonesia has been studied by Usman (2015). Indonesian customer was found to trust Islamic bank relatively highly. However, trust in the Islamic bank does not mean those customers will becoming Islamic bank customer.

Following recent and specific extensions of the Technology Acceptance Model (TAM), only a few studies centered on factors affecting the acceptance of such mobile apps from a holistic perspective that integrates many concepts related to trust, risk and social image theory (Lin et al., 2007). In this study, the TAM model, slightly altered by Munoz-Leiva et al. (2017) is adopted to analyze the factors affecting the acceptance of digital banking applications in Yogyakarta, Indonesia. The model is integrated with the factors of trust, risk and social image into the TAM model.

\section{Literature Review}

Digital banking application is the development of M-banking features that were previously widely used by banks in collaboration with cellular providers. The difference is that the M-Banking app is attached to the sim card, whereas the digital banking application is installed on the cell phone. Other changes that can be immediately 
seen are the applications, which are more attractive and user friendly. Generally, digital banking can be accessed in three ways: (1) using the application by downloading the digital banking service application from the app store available on the smartphone, (2) access through the provider menu, or (3) some digital banking is connected to Internet banking, so to be able to activate it must first activate an account on Internet banking.

\subsection{Technology Readiness Model}

The use of digital banking in business operational activities tends to increase in each bank. Technology and human resource readiness factors also influence the decision to adopt technology in the business process. Related to the acceptance of new technology systems, the Technology Acceptance Model (TAM), an adaptation of Theory of Reasoned Action (TRA), states that the use of technology is influenced by behavioral intent. Meanwhile, the behavioral intention is influenced by beliefs, namely, perceived usefulness and perceived ease of use. The TAM theory initially included a variable approach, but later ruled it out because of its poor impact in mediating the relationship of behavioral intention and belief (Venkatesh \& Davis, 2000).

Individual characteristics become one of the essential aspects in determining the factors that influence one's acceptance of a new information system, as stated by Parasuraman (2000) in his theory of Technology Readiness Index (TRI). Pasuraman and Colby in Ling and Moi (2007) said that the perception of a person's technology has two different perspectives, positive and negative, resulting in four dimensions of optimism, innovation, discomfort and insecurity in the readiness technology model.

Another study in Malaysia on students produced findings that mobile banking students did not show high readiness for technology and were not resistant. Besides, in research in other fields, the results show that respondents have a high desire to use e-learning, have a positive attitude to e-learning, and assume that e-learning is easy to use and useful to improve their academic achievement (Ling \& Moi, 2007). Optimism has a positive influence on perceived usefulness, but does not affect the perceived ease of use of technology. Interest in using technology is influenced by perceived usefulness but not influenced by perceived ease of use. The different results of this research are impressive in other technology readiness studies and other research subjects such as the acceptance of mobile banking technology by mobile banking users. In another model, some try to explain individual behavior regarding technological innovations applied in new contexts and the different stages of the consumer decision-making process, namely, by using the UTAUT (Unified Theory of Acceptance and Use of Technology) model (Abrahão et al., 2016).

\subsection{Technology Acceptance Model}

In the TAM model, there are two variables: usability and ease of use, to determine attitudes and intentions to use the system (Davis, 1989). Usability refers to the level where someone believes that using a particular system will improve their performance or work, and the perception of ease of use refers to the level where someone believes that using a system will undoubtedly be free of effort (Davis, 1989). Perceived characteristics are expected to influence the intention to use technology, which in turn affects the actual use of technology.

TAM is a model that explains behavioral intention. Behavioral intention and behavior are two different things; the behavioral intention is still an interest. Interest is defined as a desire to perform a behavior. While behavior is a real action or activity carried out. Thus, it can be interpreted that behavior will be done if someone has the interest to do it (Delone \& McLean, 2003). From the explanation above, the interest in using the mobile banking system can be seen as an impetus for someone to conduct behavior using the mobile banking system.

TAM has been expanded to add original models with other constructions suitable for the technology under study. For example, in the retail industry, TAM has been widely adopted to predict consumer intentions to use online shopping and consumer acceptance of mobile payments (Chen, 2008) by adding construction such as perceived trust, security and privacy (Kumar \& Mukherjee, 2013). Usability and ease of use have a positive relationship with an attitude towards mobile internet (Cheong \& Park, 2005). They also found that perceived price levels had a negative relationship with attitudes towards mobile Internet, and attitudes towards mobile Internet were found to be the most significant factors in predicting behavioral intentions to use mobile Internet. TAM proposes that usability and ease of use, as well as feeling pleasure, can anticipate behavioral intentions among mobile technology users. Factors that influence technology acceptance according to TAM include external factors (individual characteristics), perceived ease of use and perceived usefulness. In addition to the TAM variables, there are other variables examined by the development of the TAM model by Munoz-Leiva et al. (2017). Explanation of each variable used in the research model follows.

\subsubsection{Perceived Ease of Use}

Perceived ease of use has been defined by Davis (1989) as the extent to which a person believes that using a particular system will be free of effort. Consumer behavior research found that consumers who feel the benefits and conveniences of the system affect the intention of consumer behavior towards the system (Gao \& Bai, 2014). Ease of use 
is defined as the extent to which potential users expect the target system to be free of effort (Venkatesh \& Smith, 2013). Perceived ease of use, which is defined as the perception of ease, is one's perception that using technology can be easily understood and applied. In other words, perceived ease of use is a level of confidence in the ease of using an application in carrying out its activities.

\subsubsection{Perceived Usefulness}

Perceived usefulness is defined by how much a person thinks that a system will enhance their work's performance (Davis, 1989). Prior studies on consumer behavior found that consumers who felt the ease of use and usefulness of the system could influence the intention of consumer behavior towards the system (Gao \& Bai, 2014). Perceived usefulness is also described as the extent to which a particular person believes in improving performance through the use of a technological system (Bangkara \& Mimba, 2016).

Individuals evaluate the consequences of their behavior in terms of perceived benefits. This perception is based on the choice of their behavior on the desirability of use (Kim et al., 2007). Trust can enhance certain aspects of perceived usefulness (Gefan et al., 2003). Perceived usefulness provides reliable predictions for predicting the use of selfpredicted decision models. These results confirm that there is a high correlation between perceived usefulness and one's intention to use the system.

\subsubsection{Attitude Towards Use}

The variable of digital banking acceptance is measured based on the attitude towards the use of digital banking (attitude towards using digital banking). Attitude towards use is a person's attitude towards an object is a function of his beliefs about that object and is an assessment response related to his beliefs.

\subsubsection{Intention to Use}

Intention to use is someone's desire (interest) to use a specific behavior. A person's interest in behaving is predicted by his attitude towards his behavior and how he thinks others will judge him if he performs the behavior (Davis et al., 1989). Interest is also the mind's constant tendency to pay attention and remember some activities or activities. So, someone who is interested in an activity and pays attention to that activity must be based on pleasure, and if pleasure arises, then, someone will consistently use it in the future. In carrying out its functions, Interest is closely related to thoughts and feelings. Humans make judgment and determine after choosing and making decisions. Interest is the tendency of a big heart towards something that arises because of a need, which is felt or not felt or the desire of a thing. Factors that generate interest can be classified as follows: 1) internal needs factors. These needs can be in the form of physical and psychological needs; 2) social motive factors, the emergence of interest in a person, can be driven by social motives, namely, the need to get recognition, appreciation from the environment where he is; and 3) emotional factors. They measure someone's intensity in paying attention to a particular activity or object.

\subsubsection{Social Image}

The statement about a social image is described as the prestige that arises as a user and a higher status than nonusers. He also illustrates the extent to which users can gain respect and admiration from peers on their social media because of their IT use (Lin \& Bhattacherjee, 2010). This social image is essential because an innovation/new thing can cause feelings of uncertainty about the consequences of its use; therefore, customers can choose to seek other people's advice on personal opinions and or personal experiences (Muñoz-Leiva et al., 2017).

\subsubsection{Perceived Trust}

The statement regarding perceived trust is perceived as a commitment to maintaining digital banking, trust in digital banking application and its reliability.

\subsubsection{Perceived Risk}

Perceived risk is defined as the level of uncertainty that users face in certain buying situations (Cox \& Rich, 1964). Perceived risk for digital banking users refers to the worst expectations in finding the best results from the adoption of digital banking services (Yousafzai et al., 2003). So, this perceived risk or uncertainty affects one's confidence in technology adoption decisions. The more perceived risk, the adoption of mobile banking will be increasingly avoided, and vice versa (Al Kailani \& Kumar, 2011).

\subsection{Hypotheses}

Many theories and models of behavioral judgment have been established to analyze user behavior towards the adoption of innovative technology. Based on the purpose of this study, the model to be used is in accordance with the theory of attitude based on social psychology, such as the Technology Acceptance Model (Davis et al., 1989).

Perceived ease of use is defined as the degree to which an individual believes that in an organizational context, the use of a system will be effortless (Davis et al., 1989). This 
estimate is based on a measure to determine how the system allows a task to be carried out faster, increase productivity and performance, and work efficiency. Related to this, hypothesis 1 is proposed as follows:

\section{H1: Perceived ease of use has a significant effect on attitude toward the use.}

In addition, it was found on the basis of other studies that ease of use in virtual and electronic banking communities has a positive impact in terms of usability (Muñoz-Leiva et al., 2012). In connection with this, hypothesis 2 is proposed as follows:

\section{H2: Perceived ease of use has a significant effect on perceived usefulness.}

In accordance with the original TAM model, perceived usefulness has been applied to various fields of IT that are used to measure the performance of work, life, and study (Liu \& Li, 2011). According to Davis, perceived usefulness can be defined as the degree to which a person believes the use of a system will improve the performance of his work (Davis, 1989). The variable is relevant in this study because the digital banking application is considered innovative, and the usability given to consumers is closely linked to the benefits it provides. Several studies have demonstrated a direct connection between perceived usefulness and attitude (Aboelmaged \& Gebba, 2013) and have a relationship with the intention to use. In connection with this, hypothesis 3 is proposed as follows:

H3: Perceived usefulness has a significant effect on the attitude towards use.

Studies on the effects of perceived usefulness on new technologies have brought different results. Some studies support a significant and positive impact on the intention to use (Pham \& Ho, 2015), although others have no substantial results in this connection ( $\mathrm{Liu} \& \mathrm{Li}, 2011$ ). Related to this, hypothesis 4 is proposed as follows:

\section{H4: Perceived usefulness has a significant impact on the intention to use.}

In addition, both TRA and TAM demonstrated that attitude is a significant antecedent of intent when used to evaluate particular behaviors. According to Fishbein and Ajzen, attitude can be described as a multidimensional form, which consists of three dimensions: cognitive, affective, or emotional and connectivity or behavioral dimensions (Hill et al., 1977). In accordance with the explanation above, hypothesis 5 is proposed as follows:

\section{H5: Attitude toward use has a significant effect on the intention to use.}

In this study, we investigated the influence of external factors, namely, social image, perceived trust, and perceived risk. According to Goffman, social image is the social value that everyone wants to create through interaction with others (Goffman, 1967). In this research, social image is essential because innovation can give users a feeling of uncertainty about the consequences of its use, and, thus, give users the opportunity to try other opinions and their personal experiences.

To maintain a different social image, the presence of others around the user to strengthen or reject the image becomes necessary. Thus, hypothesis 6 is proposed as follows:

\section{H6: Social image has a significant effect on perceived ease of use.}

Besides, social image is also able to encourage the use of mobile application services, as found in (Rejón-Guardia et al., 2020). Thus, hypothesis 7 is proposed as follows:

\section{H7: Social image has a significant effect on perceived usefulness.}

In other researchers, the social image can also be able to influence attitudes towards car banking services directly. Therefore, hypothesis 8 is proposed as follows:

\section{H8: Social image has a significant effect on attitude toward the use.}

Traditionally, trust has been established through two primary components: the cognitive component that defines trust as the assumption that the word or commitment of another party is trustworthy and fulfills obligations and the behavioral component that is characterized as the will or willingness to obey a particular pattern of behavior (Liébana-Cabanillas et al.. In fact, most online transactions are practically no guarantee; consumers cannot ensure that sellers will not use undesirable behavior. The creation of trusts can compensate for these security and privacy concerns so that companies look for appropriate and efficient ways to increase the perceived trust of their sales transactions. Therefore, hypothesis 9 is proposed as follows:

\section{H9: Perceived trust does not have a significant effect on perceived risk.}

In this study, trust is suggested as an antecedent of ease of use, based on the premise that confidence reduces the need to understand, manage and track situations, to encourage the use of resources without much effort for users. Therefore, hypothesis 10 is proposed as follows: 
H10: Perceived trust has a significant effect on perceived ease of use.

Many studies also show a positive relationship between trust and attitude and between trust and risk (Park \& Tussyadiah, 2017). Therefore, hypothesis 11 is proposed as follows:

\section{H11: Perceived trust has a significant effect on attitude toward the use.}

Each user behavior is associated with certain risks because the consequences of that behavior cannot be adequately assessed beforehand. Perceived risk is a multidimensional type based on several factors, which explain the overall risk associated with the implementation of specific innovations technologies, purchases or services. Various studies have revealed that perceived risk negatively influences attitude and intention to adopt e-commerce and mobile payment systems (Muñoz-Leiva et al., 2017). In this study, perceived risk is significant because it is considered as a prior intention to use it. Therefore, hypothesis 12 is proposed as follows:

H12: Perceived risk does not have a significant effect on the intention to use.

The model adopted in this study is shown in Figure 1.

\section{Methodology}

The samples in this study are the customers of Bank Rakyat Indonesia (BRI) in the city of Yogyakarta and surrounding areas who use BRI's digital banking application. BRI is the largest state-owned bank in Indonesia, which has the most branch offices and is spread all over the country. The choice of BRI digital banking users in Yogyakarta was chosen as the respondent because of the uniqueness of the character of the Yogyakarta people who still maintain the Javanese custom, but are already used to mobile technology such as digital banking applications for financial transactions.

The number of customers who are respondents is 300 so that they meet the criteria for testing using SEM analysis. To conduct a hypothesis assessment, the researcher uses the Structural Equation Model (SEM) analysis because SEM can estimate multiple relationships and the relationship of relationships when explaining measurement errors in the estimation process (Hair et al., 2010). SEM is a multivariate statistical technique that can analyze latent variables, indicator variables and measurement errors directly. Researchers use SEM because this model provides a conceptually, exciting way of testing for testing a theory. If a researcher expresses a theory that explains the relationship between the measured variables, SEM assesses the suitability of the theory with reality, as illustrated in the data.

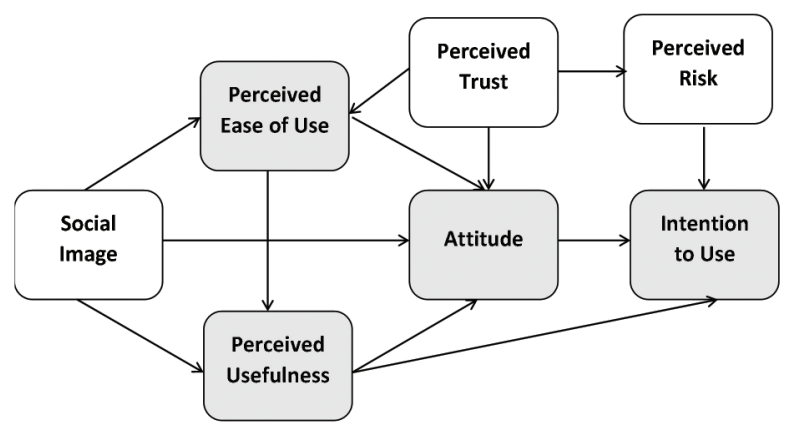

Figure 1: TAM Model, Munoz-Leiva Modification (Muñoz-Leiva et al., 2017)

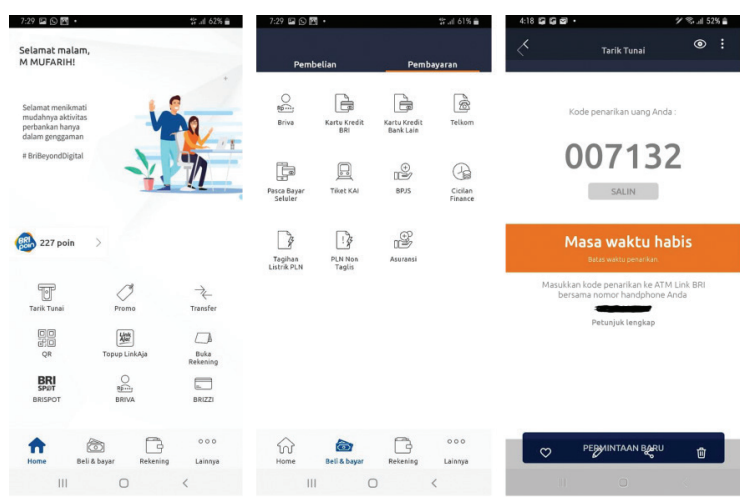

Figure 2: Digital Banking Application Menu 
Before conducting data analysis and interpretation, the questionnaire needs to be tested for its validity and reliability first. This is intended to determine the extent of the accuracy and accuracy of an instrument in carrying out the function of its measuring instrument or providing measurement results that are following the level of validity and reliability according to the specified limits.

SEM assumption testing is often conducted, recognizing that there are many conditions to be met in the SEM analysis, including criteria for sample size, no outlier data in the model, standard univariate and multivariate data and no multicollinearity in model. To test the suitability of the model, several Goodness of Fit Test (GOF) models are used. This GOF measure consists of three, namely absolute, comparative, and parsimony measures. The structural model compatibility test in SEM analysis is done by looking at several criteria of Goodness of fit models such as Chi-Square value, probability, df, GFI, AGFI, TLI, CFI, RMSEA and RMR.

\section{Result and Discussion}

A validity and reliability test for each construct was calculated to test the measurement model. Testing the construct's validity can be achieved by looking at the value of each indicator's load factor within the construct, while the reliability of the construct can be done by looking at the Average Variance Extracted (AVE) and Construct Reliability (CR) values of each construct. In this test, all indicators are declared valid because the analysis results show that the Loading factor value of all indicator variable questions is> 0.5 . Likewise, when construct reliability testing is carried out by looking at the AVE and CR values each construct. In this test, all constructs are declared reliable because all indicator variables show the calculation of $\mathrm{AVE}>0.5$ and $\mathrm{CR}>0.7$.

Another test performed is to test the SEM assumptions, including the sufficient number of samples, no outlier data are available in the model, and the data is normally distributed. The number of samples used in this study is 300 samples, which means the number of samples has exceeded the adequacy requirements for the number of samples in the SEM analysis. Outlier detection results show that of the 300 data analyzed, there are no data that have an expensive aerobic distance above 55.476, so it is considered that there are no outliers in the analyzed data. The normality test is done by looking at the value of CR skewness or kurtosis. The test results show that the research data are typically distributed because the univariate kurtosis values of all indicators are in the interval $-2.58<\mathrm{z}<2.58$ as well as the multivariate $\mathrm{CR}$ value of -2.308 indicating that the multivariate $C R$ is in the -2.58 interval $<\mathrm{z}<2.58$ goodness of fit testing.
Table 1: Goodness of Fit Model Test Results

\begin{tabular}{|l|c|c|l|}
\hline GoF Index & $\begin{array}{c}\text { Cut of } \\
\text { Value }\end{array}$ & $\begin{array}{c}\text { Analysis } \\
\text { Result }\end{array}$ & $\begin{array}{c}\text { Model } \\
\text { Evaluation }\end{array}$ \\
\hline$X^{2}$ chi square & $<689,991$ & 619,185 & Good Fit \\
\hline Probability & $\geq 0,05$ & 0,089 & Good Fit \\
\hline RMSEA & $\leq 0,08$ & 0,054 & Good Fit \\
\hline GFI & $\geq 0,90$ & 0,725 & Marginal Fit \\
\hline AGFI & $\geq 0,90$ & 0,666 & Not Fit \\
\hline CMIN/DF & $\leq 2,00$ & 1,991 & Good Fit \\
\hline TLI & $\geq 0,95$ & 0,895 & Good Fit \\
\hline CFI & $\geq 0,95$ & 0,907 & Good Fit \\
\hline
\end{tabular}

The next test is the structural model fit test, which is by looking at the Goodness of fit (GOF) criteria of the model, such as Chi-Square value, probability, df, GFI, AGFI, TLI, CFI RMSEA and RMR. In Table 1 below shows the results of the model test, whether it meets the criteria of goodness of fit models that are good or not.

Hypothesis testing in this study is done by looking at whether there is a significant influence of exogenous variables on endogenous variables. A relationship called significant at the $95 \%$ confidence level if the value of the Critical Ratio $(\mathrm{CR}) \geq 1.96$ or the probability value $(\mathrm{p}) \leq$ 0.05 . Thus, it can be said that a hypothesis is accepted if the value of $C R \geq 1.96$ or $p$-value $\leq 0.05$, and vice versa, the hypothesis is rejected if the value of $\mathrm{CR}<1.96$ or $\mathrm{p}$ value $>$ 0.05 .

After analysing the data, in Figure 3 and Table 2, from 12 hypotheses submitted, eight hypotheses were accepted and four hypotheses were rejected. Perceived ease of use has a positive influence on perceived usefulness, but has no effect on attention toward use. Perceived usefulness apparently does not affect attitude toward use or intention to use. Nevertheless, the intention to use is positively influenced by attitude toward use. Social image, which is an additional variable from the initial TAM theory model, was found to have a significant effect on perceived ease of use and on perceived usefulness, but did not influence attention toward use. While perceived trust is proven to have no influence on perceived risk, so intention to use is indeed proven not to be affected by perceived risk. Besides that, it is also found that perceived trust has a significant influence on perceived ease of use and attitude toward use. 


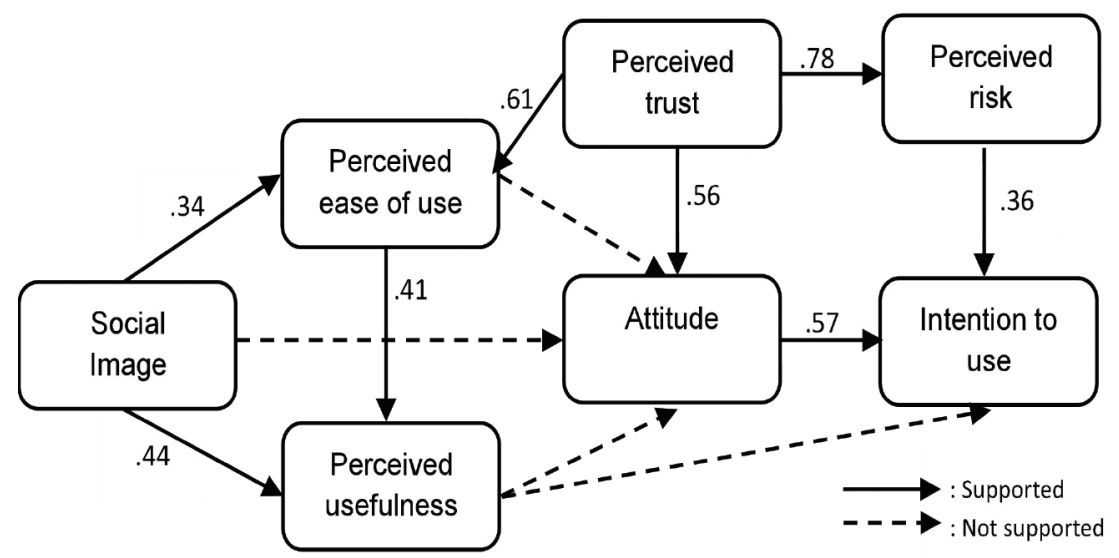

Figure 3: Result Model

Table 2: Significance Test Results

\begin{tabular}{|c|c|c|c|c|c|}
\hline Hypothesis & Estimate & SE & CR & $\mathbf{P}$ & Result \\
\hline $\mathrm{PEOU} \rightarrow \mathrm{AT}$ & .027 & .136 & .201 & .840 & Not Supp. \\
\hline PEOU $\rightarrow$ PU & .413 & .107 & 3.846 & .000 & Supported \\
\hline $\mathrm{PU} \rightarrow \mathrm{AT}$ & .163 & .133 & 1.230 & .219 & Not Supp. \\
\hline $\mathrm{PU} \rightarrow \mathrm{IU}$ & .006 & .063 & .100 & .921 & Not Supp. \\
\hline AT $\rightarrow$ IU & .571 & .146 & 3.902 & .000 & Supported \\
\hline $\mathrm{SI} \rightarrow \mathrm{PEOU}$ & .340 & .118 & 2.876 & .004 & Supported \\
\hline $\mathrm{SI} \rightarrow \mathrm{PU}$ & .441 & .114 & 3.866 & .000 & Supported \\
\hline $\mathrm{SI} \rightarrow \mathrm{AT}$ & .127 & .135 & .936 & .349 & Not Supp. \\
\hline $\mathrm{PT} \rightarrow \mathrm{PR}$ & -.784 & .100 & -7.863 & .000 & Supported \\
\hline PT $\rightarrow$ PEOU & .607 & .131 & 4.630 & .000 & Supported \\
\hline $\mathrm{PT} \rightarrow \mathrm{AT}$ & .559 & .173 & 3.223 & .001 & Supported \\
\hline $\mathrm{PR} \rightarrow \mathrm{IU}$ & -.360 & .127 & -2.832 & .005 & Supported \\
\hline
\end{tabular}

The analysis shows that perceived use does not have a significant effect on attention toward use. This is different from some other studies where perceived use has a significant effect on attention toward use. In this case, perception of convenience is not a determining factor in their behavioral attitudes using a digital banking application. The variable perceived ease of use has a significant and positive effect on perceived usefulness. This shows that the higher the user's perception of the ease of use of the digital banking application, the better the perception of the usefulness or benefits of the digital banking application. Other research conducted on virtual communities in the field of electronic banking also proves the same thing (Muñoz-Leiva et al., 2012).

The next hypothesis about perceived usefulness is thought to have an influence on attitude to use digital banking applications. However, this hypothesis was rejected because, for users of digital banking applications in Yogyakarta, it turns out that the perception of ease of use of a banking application does not give them the desire or attention to use the application. It will be proven later that attention to the use of digital banking applications in Yogyakarta is influenced by other factors. The variable perceived usefulness is proven to have no significant effect on the intention to use. Indeed, there are several studies that produce different outputs. There are studies that support a significant and positive effect on the intention to use (Pham \& Ho, 2015), while other studies do not show significant results for this relationship (Liu \& Li, 2011).

Testing the following hypothesis shows that attitude toward using has a positive and significant effect on the intention to use, the higher the user's attitude towards the 
digital banking application, the higher the user's interest in using the digital banking application. Studies conducted with the TRA and TAM models have shown that attitude is an essential antecedent of intention when it is used to develop specific behaviors.

The results of the next hypothesis are that social image has a significant effect on perceived ease of use; the higher the social image value of a digital banking application, the higher the confidence that the use of a particular system can reduce one's efforts in doing something. In addition to studies from Munoz-Leiva, Goffman also said that social image is the desired social value created by each person through interaction with others (Goffman, 1967), so that if the interaction with people who have been using the same application, it will help improve perspective the convenience. In addition, the social image also has a positive and significant effect on perceived usefulness. The more positive the social image on the digital banking application, the higher the user's perception of the benefits of the digital banking application. Another study of mobile data service has proven that social image can improve perceptions of the benefits of service for users of mobile data services (Chong et al., 2012). However, towards attitude toward using, the social image has no significant effect on. This result is contrary to the two social image influences above, which are said to have a positive influence. However, if examined further, that in accordance with the previous discussion, that attitude toward using is not significantly affected by perceived ease of use, so it becomes relevant if it is found here that social image does not significantly influence attitude toward using.

Perceived trust has a negative and significant effect on perceived risk; the higher the user's trust in the digital banking application, the lower the user's risk concerns for the digital banking application. The reason for this importance is because there is no guarantee for the customer that the seller will not use undesirable behavior, such as privacy violations, the use of unauthorized credit card information, low prices or access to unauthorized transactions. Therefore, consumers will be affected by a sense of concern about privacy and control over their personal information. In other words, it can be explained that if the trust is embedded in an application, that trust will weaken the user's perspective of the risks arising from the use of the application. Analysis of other hypotheses shows that perceived trust has a positive and significant effect on perceived ease of use, so the higher the customer's trust in the digital banking application, the higher the user's perception of the ease of use of the digital banking application. Similarly, the effect of perceived trust on attitude toward using, which means the more confidence the consumer has in the digital banking application, the more the attitude of the consumer toward the digital banking app.

Finally, the effect of perceived risk on the intention to use is known to have a negative and significant effect.
The higher the user's risk concern for the digital banking application, the lower the user's interest in using the digital banking application.

\section{Conclusion}

User perception of the ease of use of the digital banking application is not a significant factor influencing customer behavior. The digital banking application has become an essential requirement for customers so that the perception of ease of use does not affect customer behavior towards the application. In addition, the perception of ease of use has an effect on the benefits felt by users, the higher the user's perception of the ease of use of the digital banking application, the higher the perceived benefits of users of the digital banking application. In other words, the digital banking application is more beneficial for its users if the application is easy to use.

Perceived usefulness does not have a significant effect on attitude toward using or intend to use. This shows that the perception of benefits is not a factor that influences the attitudes and interests of customers in the digital banking application. Although this digital banking application is used by customers, the consideration of its use is not because of the perceived benefits, but tends to other factors, outside the benefits. Attitude toward use has a positive and significant effect on the intention to use, the more positive the user's attitude towards the digital banking application, the higher the user's interest in using the digital banking application. The social image has a significant influence on perceived ease of use and perceived usefulness, but the effect is not significant on attention toward use. This means that the better the social image on the digital banking application, the higher the perceived ease of use and benefits felt by users of the digital banking application. On the other hand, social image is apparently not a factor influencing customer attitudes in using this application.

Perceived trust has a significant effect on perceived risk, perceived ease of use and attitude toward using. The higher the customer's trust, the higher the user's perception of the ease of use and user attitude of the digital banking application. As for perceived risk, perceived trust has a negative and significant influence, meaning that the higher the user's trust in the digital banking application, the lower the risk perceived by the customer is using this application. Perceived risk has a negative and significant effect on the intention to use, the higher the risk perceived by the user on the digital banking application, the lower the user's interest in using the digital banking application.

Apart from the above conclusions, the discussion in this paper is only in a very limited scope, by taking the example 
of a mobile banking application used in an area. Because of these limitations, there is the possibility of other studies with similar subjects arriving at different results. What needs to be further explored is how much domination of external factors such as social image, risk and trust in the intention to use in the decision to use the mobile banking application and whether these factors have a relationship with perceived usefulness and perceived ease of use.

\section{References}

Aboelmaged, M., \& Gebba, T. R. (2013). Mobile Banking Adoption: An Examination of Technology Acceptance Model and Theory of Planned Behavior. International Journal of Business Research and Development, 2(1), 35-50. https://doi. org/10.24102/ijbrd.v2i1.263

Abrahão, R. S., Moriguchi, S. N., \& Andrade, D. F. (2016). Intention of adoption of mobile payment: An analysis in the light of the Unified Theory of Acceptance and Use of Technology (UTAUT). RAI Revista de Administração e Inovação, 13(3), 221-230. https://doi.org/10.1016/j.rai.2016.06.003

Al-Kailani, M., \& Kumar, R. (2011). Investigating Uncertainty Avoidance and Perceived Risk for Impacting Internet Buying: A Study in Three National Cultures. International Journal of Business and Management, 6(5). https://doi.org/10.5539/ijbm. v6n5p76

Alalwan, A. A., Dwivedi, Y. K., \& Rana, N. P. (2017). Factors influencing adoption of mobile banking by Jordanian bank customers: Extending UTAUT2 with trust. International Journal of Information Management, 37(3), 99-110. https://doi. org/10.1016/j.ijinfomgt.2017.01.002

Baabdullah, A. M., Alalwan, A. A., Rana, N. P., Kizgin, H., \& Patil, P. (2019). Consumer use of mobile banking (M-Banking) in Saudi Arabia: Towards an integrated model. International Journal of Information Management, 44(July 2018), 38-52. https://doi.org/10.1016/j.ijinfomgt.2018.09.002

Bangkara, R. P., \& Mimba, N. P. S. H. (2016). Pengaruh Perceived Usefulness dan Perceived Ease of Use pada Minat Penggunaan Internet Banking dengan Attitude toward Using sebagai Variabel Intervening. E-Jurnal Akuntansi Universitas Udayana, $16,2408-2434$.

Chen, L. (2008). A model of consumer acceptance of mobile payment. International Journal of Mobile Communications, 6(1), 32-52. DOI: 10.1504/IJMC.2008.015997

Cheong, J., \& Park, M. C. (2005). Mobile internet acceptance in Korea. Internet Research, 15(2), 125-140. https://doi. org/10.1108/10662240510590324

Chong, A. Y. L., Ooi, K. B., Lin, B., \& Bao, H. (2012). An empirical analysis of the determinants of $3 \mathrm{G}$ adoption in China. Computers in Human Behavior, 28(2), 360-369. https://doi. org/10.1016/j.chb.2011.10.005

Cox, D. F., \& Rich, S. U. (1964). Perceived Risk and Consumer Decision-Making: The Case of Telephone Shopping. Journal of Marketing Research, 1(4), 32. https://doi.org/10.2307/3150375
Davis, F. D. (1989). Perceived Usefulness, Perceived Ease of Use, and User Acceptance of Information Technology. MIS Quarterly, 13(3), 319-340. DOI: 10.2307/249008

Davis, F. D., Bagozzi, R. P., \& Warshaw, P. R. (1989). User Acceptance of Computer Technology: A Comparison of Two Theoretical Models. Management Science, 35(8), 982-1003. DOI: $10.2307 / 2632151$

Delone, W. H., \& McLean, E. R. (2003). The DeLone and McLean Model of Information Systems Success: A Ten-Year Update. Journal of Management Information Systems, 19(4), 9-30. https://doi.org/10.1080/07421222.2003.11045748

Gao, L., \& Bai, X. (2014). A unified perspective on the factors influencing consumer acceptance of internet of things technology. Asia Pacific Journal of Marketing and Logistics, 26(2), 211-231. https://doi.org/10.1108/APJML-06-2013-0061

Gefan, D., Karahanna, E., \& Straub, D. W. (2003). Trust and TAM in Online Shopping: An Integrated Model. MIS Quarterly, 27(1), 51-90. DOI: 10.2307/30036519

Goffman, E. (1967). Interaction On Ritual: essay in face-to-face Behavior. Chicago, IL: Aldine Publishing Company.

Hair, J. F., Black, W. C., Babin, B. J., \& Anderson, R. E. (2010). Multivariate Data Analysis. New York, NY: Pearson.

Hill, R. J., Fishbein, M., \& Ajzen, I. (1977). Belief, Attitude, Intention and Behavior: An Introduction to Theory and Research. Contemporary Sociology, 6(2), 244. https://doi. org/10.2307/2065853

Kim, H. W., Chan, H. C., \& Gupta, S. (2007). Value-based Adoption of Mobile Internet: An empirical investigation. Decision Support Systems, 43(1), 111-126. https://doi.org/10.1016/j. dss.2005.05.009

Kumar, A., \& Mukherjee, A. (2013). Shop While You Talk: Determinants of Purchase Intentions through A Mobile Device. Mobile Marketing Association, 8(1), 23-37.

Le, H. B. H., Ngo, C. T., Trinh, T. T. H., \& Nguyen, T. T. P. (2020). Factor affecting customers' decision to use mobile banking service: A case of thanh hoa province, Vietnam. Journal of Asian Finance, Economics and Business, 7(2), 205-212. https:// doi.org/10.13106/jafeb.2020.vol7.no2.205

Liebana-Cabanillas, F., Munoz-Leiva, F., \& Sanchez-Fernandez, J. (2017). A global approach to the analysis of user behavior in mobile payment systems in the new electronic environment. https://doi.org/10.1007/s11628-017-0336-7

Liébana-Cabanillas, F., Sánchez-Fernández, J., \& Muñoz-Leiva, F. (2014). The moderating effect of experience in the adoption of mobile payment tools in Virtual Social Networks: The m-Payment Acceptance Model in Virtual Social Networks (MPAM-VSN). International Journal of Information Management, 34(2), 151-166. https://doi.org/10.1016/j. ijinfomgt.2013.12.006

Lin, C.-H., Shih, H.-Y., \& Sher, P. J. (2007). Integrating technology readiness into technology acceptance: The TRAM model. Psychology \& Marketing, 24(7), 641-657. https://doi. org/10.1002/mar 
Lin, C., \& Bhattacherjee, A. (2010). Extending technology usage models to interactive hedonic technologies: a theoretical model and empirical test. 163-181. https://doi.org/10.1111/j.13652575.2007.00265.x

Ling, L. M., \& Moi, C. M. (2007). Professional Students' Technology Readiness, Prior Computing Experience and Acceptance of An E-Learning System. Malaysian Accounting Review, 6(1).

Liu, Y., \& Li, H. (2011). Exploring the impact of use context on mobile hedonic services adoption: An empirical study on mobile gaming in China. Computers in Human Behavior, 27(2), 890-898. https://doi.org/10.1016/j.chb.2010.11.014

Muñoz-Leiva, F., Climent-Climent, S., \& Liébana-Cabanillas, F. (2017). Determinants of Intention to use the mobile banking apps: An extension of the classic TAM model. Spanish Journal of Marketing - ESIC, 21(1), 25-38. https://doi.org/10.1016/j. sjme.2016.12.001

Muñoz-Leiva, F., Hernández-Méndez, J., \& Sánchez-Fernández, J. (2012). Generalising user behaviour in online travel sites through the Travel 2.0 website acceptance model. Online Information Review, 36(6), 879-902. https://doi. org/10.1108/14684521211287945

Nguyen, O. T. (2020). Factors Affecting the Intention to Use Digital Banking in Vietnam. Journal of Asian Finance, Economics and Business, 7(3), 303-310. https://doi.org/10.13106/jafeb.2020. vol7.no3.303

Parasuraman A. (2000). Technology Readiness Index (TRI): A Multipleitem Scale To Measure Readiness To Embrace New Technologies. Journal of Service Research, 2(4), 307-320. https://doi.org/10.1177/109467050024001

Park, S., \& Tussyadiah, I. P. (2017). Multidimensional Facets of Perceived Risk in Mobile Travel Booking. Journal of Travel Research, 56(7), 854-867. https://doi. org/10.1177/0047287516675062

Pham, T. T. T., \& Ho, J. C. (2015). The effects of product-related, personal-related factors and attractiveness of alternatives on consumer adoption of NFC-based mobile payments. Technology in Society, 43, 159-172. https://doi.org/10.1016/j. techsoc.2015.05.004
Pousttchi, K., \& Schurig, M. (2004). Assessment of Today's Mobile Banking Applications from the View of Customer Requirements. In: Proceedings of the 37th Annual Hawaii International Conference on System Sciences. DOI: 10.1109/ HICSS.2004.1265440

PricewaterhouseCoopers. (2018). PwC Survey: Digital Banking in Indonesia 2018. (July). https://www.pwc.com/id/en/ publications/assets/financialservices/digital-banking-survey2018-pwcid.pdf

Rejón-Guardia, F., Polo-Peña, A. I., \& Maraver-Tarifa, G. (2020). The acceptance of a personal learning environment based on Google apps: the role of subjective norms and social image. Journal of Computing in Higher Education, 32(2), 203-233. https://doi.org/10.1007/s12528-019-09206-1

Rilling, S., \& Debbie Harrison. (2015). Mobile Banking Acceptance among Young Consumers In Germany: An Empirical Analysis. Master's thesis, the Universidade Católica Portuguesa. https:// repositorio.ucp.pt/bitstream/10400.14/19962/1/Master\%20 Thesis\%20Catolica.pdf

Shaikh, A. A., \& Karjaluoto, H. (2014). Mobile banking adoption: A literature review. Telematics and Informatics, 32(1), 129142. https://doi.org/10.1016/j.tele.2014.05.003

Usman, H. (2015). Customers trust on Islamic banks in Indonesia. Journal of Asian Finance, Economics, and Business, 2(1), 5-13. https://doi.org/doi.org/10.13106/jafeb.2015.vol2.no1.5

Venkatesh, V., \& Davis, F. D. (2000). A Theoretical Extension of the Technology Acceptance Model: Four Longitudinal Field Studies. Management Science, 46(2), 186-204. DOI: 10.1287/ mnsc.46.2.186.11926

Venkatesh, V., \& Smith, R. H. (2013). Creation of Favorable Creation User Perceptions: The Role of Intrinsic Motivation. 23(2), 239-260.

Voon, J.-J. H., Keng, H. L., \& Wei, B. O. J. (2015). What catalyses mobile apps usage intention: An empirical analysis. Industrial Management \& Data Systems, 115(7), 1182-1203. https://doi. org/10.1108/02635570710734262

Yousafzai, S. Y., Pallister, J. G., \& Foxall, G. R. (2003). A proposed model of e-trust for electronic banking. Technovation, 23(11), 847-860. https://doi.org/10.1016/S0166-4972(03)00130-5 